\title{
Economic and Environmental Issues in International Trade and Production of Genetically Modified Foods and Crops and the WTO
}

\author{
J. R. Pillarisetti and Kylie Radel \\ Central Queensland University
}

\begin{abstract}
International trade in agriculture is growing rapidly under the auspices of the WTO. Within agriculture, a recent contentious issue relates to trade in genetically modified foods and crops. This paper examines a variety of issues associated with these foods and crops both from advanced and developing countries perspectives. The paper notes significant concerns from a variety of perspectives
\end{abstract}

- JEL Classifications: Q1, Q17, Q28, O13.

- Key words: Sustainable agriculture, Genetically modified organisms (GMOs), Trade, WTO

\section{Introduction}

International trade in agricultural products is growing rapidly. The World Trade Organisation's (WTO) Agreement on Agriculture (AoA) aims to liberalize agricultural trade between nations and intends to obtain so-called "free trade" by lowering tariffs and by removing non-tariff barriers to trade (Chapman 1999). Chapman (1999) also suggests that "there [are] three main areas of reform [in the agreement]: the improvement of market access for imports, the reduction of domestic support/national subsidies, and the elimination of export subsidies."

Within the agricultural arena, a recent phenomenon is the growth in production

\footnotetext{
*Corresponding address: J.R. Pillarisetti, Faculty of Business and Law, Central Queensland University, Rockhampton, QLD 4702, Australia Tel: +617-4930-9510, Fax: +617-4930-9700, E-mail: r.pillarisetti@cqu. edu.au and Kylie Radel Faculty of Business and Law, Central Queensland University, Rockhampton, QLD 4702, Australia. Tel: +617-4930 9690, Fax: +617-4930 9700, E-mail: k.radel@cqu.edu.au. (C)2004-Center for International Economics, Sejong Institution, All Rights Reserved.
} 
and trade of biotechnologically generated food or genetically modified (GM) food or genetically modified organisms (GMOs). The crucial question is whether the current laws and guidelines of the WTO are sufficient to ensure desirable outcomes with regard to agricultural production, trade between nations and national well-being. This paper examines a broad spectrum of issues relating to genetically modified foods and crops in relation to trade and the well-being of consumers in advanced and developing nations. The paper is organised as follows: Section 2 discusses the ecological, social and ethical concerns in GM agriculture; Section 3 examines the WTO rules and GMOs including the Precautionary and Substantial Equivalence Principles; Section 4 describes the geographical and industrial concentration relating to GMOs; Section 5 explains consumer perceptions of GM agriculture and GM foods; Section 6 addresses GMOs from developing nation perspectives; Section 7 briefly comments on the "Biosafety Protocol"; and Section 8 provides concluding remarks.

\section{Ecological, Social and Ethical Concerns in GM Agriculture}

Genetically modified (GM) or genetically engineered (GE) foods are those that come from seeds or the plant material that have their genetic makeup altered by scientists. These foods are often created by inserting genes from totally unrelated species. GM crops and foods are different from those obtained through traditional cross breeding in a number of ways: i) GMOs allow for the splicing of genes that do not occur through natural processes; ii) there is inexact or haphazard insertion of a trait DNA into a chromosome; and iii) GM crops can display instability while the crops from traditional cross breeding demonstrate stable traits. Nobel Laureate in Medicine, Dr. George Wald (1976) states that:

Recombinant DNA technology [genetic engineering] faces our society with problems unprecedented not only in the history of science, but of life on the Earth. It places in human hands the capacity to redesign living organisms, the products of three billion years of evolution. Such intervention must not be confused with previous intrusions upon the natural order of living organisms: animal and plant breeding...All such earlier procedures worked within single or closely related species... Our morality up to now has been to go ahead without restriction to learn all that we can about nature. Restructuring nature was not part of the bargain...this direction may be not only unwise, but dangerous. Potentially, it could breed new animal and plant diseases, new sources of cancer, novel epidemics (Wald, 1976 in Jackson \& Stich, 1979, pp. 127-128) 
During the $20^{\text {th }}$ Century, a tendency towards using monoculture crops (together with heavy dependence on chemicals) showing high yield resulted in a loss of three quarters of genetic diversity in crops and increased risk. The quantity of crop output is increased but the nutritional value of these crops is reduced. Moreover, uncontrolled use of antibiotics and growth hormones is resulting in numerous health problems in animals and humans (eg, Kimbrell, 2002; Mellon, Benbrook and Benbrook, 2001; Pretty et al., 2000). These consequences of conventional (often termed 'factory farming') agriculture are extensive and often intangible. For instance, media reports place the cost of a recent Foot and Mouth outbreak at \$60 billion. Estimates of the cost of Mad Cow disease Bovine Spongiform Encephalopathy (BSE) vary with some reports placing it at $\$ 180$ billion, but the full impact of BSE is substantial, worldwide and still unknown.

While conventional agriculture is causing environmental and health risks, GM food and crops are a cause for further concern for a variety of reasons. These include:

(i) unnatural gene transfers, such as for instance between fish and tomatoes and other unrelated species, which do not happen in nature and may create new toxins or rogue genes;

(ii) adverse health effects due to 'position effect' which reflect unpredictable patterns of gene expression and genetic function;

(iii) introduction of new allergens and toxins into food. A genetically modified corn 'StarLink' approved for livestock feed has entered the human food chain and being a human allergen caused reactions ranging from rashes to breathing problems (Vorman, 2001);

(iv) the use of hormones and GMOs which impact negatively on livestock or the environment - for instance, a genetically altered milk hormone, the recombinant Bovine Growth Hormone (rBGH), which aims to increase dairy production by 10 percent was rejected by Canada when testing indicated that the drug can cause a variety of problems for the cattle such as "udder infections, painful, debilitating foot disorders, and reduced life span in treated cows" (Environmental Research Foundation, 1999);

(v) the herbicide-resistant crops (forming over half of GM crop related research) can result in the increased use of chemicals in the medium to long term. In one case, weed scientists at the University of Kansas (USA) reported a record number of complaints about spray-drift from neighbouring properties at the same time as the cultivation of herbicide-resistant crops (Clinch-Jones, 2003); 
(vi) many ethical concerns for religious people and vegetarian groups result from the grotesque nature of gene transfers, such as transfers from arctic flounder fish to tomatoes, genes from mice transferred into corn varieties and genes from the cholera toxin which have been transferred to alfalfa (Kanniah, 2001);

(vii) GM crops may also pose a threat to organic and bio-dynamic agriculture and natural plant species through cross contamination, cross pollination and creation of pests resistant to natural Bacillus thuringiensis (Bt) toxins (Crouch, 1995);

(viii) Inadequate safeguards at research facilities are causing genetic contamination (such as the escaping of GM fish to open oceans (see, Atlantic Salmon Federation, 2001; Muir and Howard, 1996)); and

(ix) Many of the GM crop patents involve "biopiracy" of indigenous knowledge and plants used by many local communities for centuries (Shiva, 1997).

Given the complexity of genetic coding, it is difficult to predict the effects of genetic modifications. The risks associated with GM foods are unknown and may be substantial (Rissler and Mellon, 1996). Safety concerns are prevalent in many of the European Union Member Nations. In Germany, these concerns led to the creation of a new ministry in January 2001, which administers food, agriculture, and consumer protection. German Foreign Minister, Joschka Fisher stated that "Europeans do not want genetically modified food period. It does not matter what research shows, they just do not want it and that has to be respected" (Rural Migration News, 2001, pp.1).

\section{WTO Rules, Precautionary Principle and GMOs}

Using the 'substantial equivalence' concept, GM food companies have circumvented the issues of food safety, especially the long-term consequences to health, environment and bio-diversity. The principle of substantial equivalence assumes that if it has been established that the GMO is comparable to its natural counterpart, it can then be assumed that there is no reason for the product to be hazardous. A limited set of characteristics are tested on the GM food (the characteristics are selected by the manufacturer) and if no significant difference emerges then the food is deemed safe for consumption and no further testing is entered into (Physicians and Scientists for Responsible Application of Science and Technology, 1998). Research by Professor Arpad Pusztai and Stanley Ewen has shown that lab rats fed with GM potatoes spliced with lectin suffered damage to 
internal organs (Biodemocracy News, 2001; Ho and Ching, 2003). This shows that substantial equivalence does not imply safety of food. Wills (2001) suggests there is an unsatisfactory degree of accuracy in the scientific research as to what happens when an organism is genetically engineered - the processes of genetic engineering are inherently unstable and unpredictable.

Briefly, the precautionary principle (in opposition to the use of the principle of substantial equivalence which is proffered by companies as reasonable evidence that products are safe for consumption) moves the burden of proof firmly back to the proponents of the new technology/chemical/project. The precautionary principle "allows countries to regulate pesticides and GMOs [Gene Modified Organisms] on the basis of "better safe than sorry" risk assessments" (Hayden, 2003). The precautionary principle was first utilised in international law during the 1980s in a conference on the protection of the North Sea. Typically, the principle should be applied whenever there is possible risk and uncertainty with new technology and a likely risk of irreversible or serious damage to the environment (Anderson, 2000).

Through their mission, the WTO effectively circumvent three of the foundation criteria of environmental protection which include: (i) utilising bans to prevent pollution, (ii) employing the precautionary principle, and (iii) allowing consumer choice and the 'right-to-know' through clear and concise labelling of products. Most importantly, the use of, and sale of, GM technologies for crops, foods and livestock products and research specifically violates the second and third of these foundation criteria.

The WTO has declared these concerns and principles discriminatory. In case of point, the WTO rules undermine environmental protection on three levels whereby:

(i) the method of production can not be used as a basis for discriminating against a product. "The ability to distinguish among production methods is essential to environmental protection and environmentally sound economic policies...Trade rules that forbid the differentiation between products based on production methods make it impossible for governments to design effective environmental policies" (Ralph Nadar as quoted in Wallch and Sforza, 1999, pp.23);

(ii) Abolition of the precautionary principle suggests that the trade restrictions must be seen to be non-restrictive and must be 'necessary'. This takes the burden of proof away from corporations and puts it squarely on governments which want to protect their citizens and their environments; 
iii) Labelling is also considered to be a trade restriction. Even voluntary labelling is discouraged. The recent EU law requiring all food containing GM ingredients to be labelled has been considered discriminatory by the US government. However, labels offer consumers the opportunity of choice through information so that they can consider issues such as ecological benefits, abolition of animal cruelty, abolition of slave labour and other issues in their shopping decisions (Browne et al., 2000; Esty and Geradin, 1998).

\section{Industrial and Geographical Concentrations of Genetic Engineering}

The size and growth of agricultural production utilising GM production techniques varies significantly across countries (Halweil, 2000).

\section{A. Land area under GM agriculture}

The GM market size in Figure 1 shows that the USA is the dominant producer and promoter of GM foods with 72 percent of production coming from the USA. Argentina and Canada produce 17 percent and 10 percent respectively. Together, these three countries account for 99 percent of GM food production. Europe and the rest of the world are unwilling to embark on GM technologies for reasons of food

Figure 1. Regional Distribution of World Land Area Under GM Cultivation

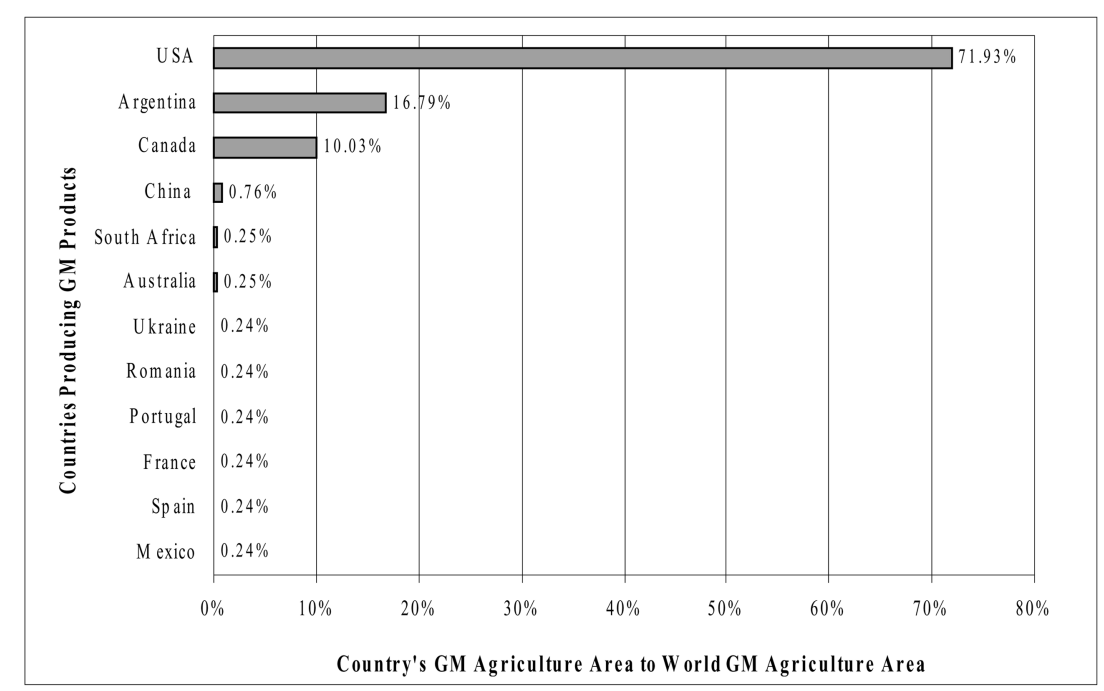

(Source: Halweil, 2000) 
safety, environment, and strong consumer reluctance to GM foods. GM in remaining countries mostly involves field trials. Note that exact data are not available for Ukraine to Mexico. Halweil (2000) gives the ratio as less than 0.25 percent ( 0.24 percent is used as an approximation). These trials could pose serious threats to the genetic purity of food in these countries. Thus we see a complete polarization in the production and consumption patterns of GM foods.

\section{B. Industrial concentration in biotechnology sector}

Biotechnology is the ultimate in corporate vertical integration, where control begins with the gene and ends at the supermarket (Richard Nilsen, Third World Biotechnology Conference, France 1987 in Australian Conservation Foundation, 2001).

The biotechnology corporate structure is highly concentrated. These technologies increasingly allow for the concentration and control of agricultural production under the auspices of a small number of large mega-corporations the majority of which are situated in the USA (Australian Conservation Foundation (ACF), 2001). For example, Monsanto-owned seed companies of Zimbabwe control entire market distribution networks which leaves struggling farmers in some of the poorest areas forced to purchase whatever such companies choose to sell (World Development Movement (WDM), 2000).

The Human Development Report (1999) has noted that mergers and acquisitions in the biotechnology industry have jumped from $\$ 9.3$ billion in 1988 to $\$ 172.4$ billion in 1998, with the top five biotechnology companies controlling more than 95 percent of patents and gene technology transfers. Seed varieties from Monsanto account for about 94 percent of the global transgenic crop area (United Nations Development Programme, 1999).

The five major corporations which are controlling the industry are chemical companies which have merged with seed companies (now known as the "Life Sciences" corporations) including Pharmacia (Monsanto - USA), DuPont (USA), Syngenta (the Combination of AstraZeneca - UK/Sweden and Novartis - Switzerland), Aventis (Germany/France) and Dow (Rural Advancement Foundation International (RAFI), 2001). Between 1996 and 1998 alone, the US agro-chemical giant Monsanto spent some $\$ 8$ billion in their mission to buy-up seed and biotechnology companies (Simms, 1999). As demonstrated in table 1, five of the seven so-called "Gene Giants" are companies which also rank among the worlds top 10 agrochemical corporations (RAFI, 2001). Syngenta and Pharmacia 
Table 1. Top Ten Agrochemical Companies for the year 2000

\begin{tabular}{lcc}
\hline \multicolumn{1}{c}{ Company } & $\begin{array}{c}\text { Agrochemical Sales } \\
\text { (US\$ Millions) }\end{array}$ & $\begin{array}{c}\text { Share of World } \\
\text { Market }\end{array}$ \\
\hline Syngenta(Novartis \&AstraZeneca) & $\$ 6,100$ & $20 \%$ \\
Pharmacia (Monsanto) & $\$ 4,100$ & $14 \%$ \\
Aventis (AgrEvo \& Rhone Poulenc) & $\$ 3,400$ & $11 \%$ \\
BASF (\& Cyanamid) & $\$ 3,400$ & $11 \%$ \\
DuPont & $\$ 2,500$ & $8 \%$ \\
Bayer & $\$ 2,100$ & $7 \%$ \\
Dow AgroSciences & $\$ 2,100$ & $7 \%$ \\
Makhteshim-Agan & $\$ 675$ & $2 \%$ \\
Sumitomo & $\$ 625$ & $2 \%$ \\
FMC & $\$ 575$ & $2 \%$ \\
Other & & $16 \%$ \\
\hline (Soure: Action Group on Erosion, Technogy
\end{tabular}

(Source: Action Group on Erosion, Technology, and Concentration (formerly RAFI) 2001, p. 9)

represent more than one third of the agrochemical sales for the world market.

Several of these mega-corporations also control a significant proportion of the world seed sales as demonstrated in Table 2 .

These mega-companies are also the controlling interests in patents for GM and agricultural biotechnology. Of the 1,370 US patents that were issued for agricultural biotechnology in 1998 some three quarters (74 percent) were awarded to six of the "Gene Giant" companies as shown in Figure 2 (RAFI, 2001).

A further issue which is being raised with regard to the level of industry concentration relates to the patenting of both the GM seeds and conventional seed

Table 2. Top 10 seed companies by sales for the year 2000

\begin{tabular}{lc}
\hline \multicolumn{1}{c}{ Company } & Seed Sales (US\$ Millions) \\
\hline DuPont (Pioneer) USA & $\$ 1,938$ \\
Pharmacia (Monsanto) USA & $\$ 1,600$ \\
Syngenta (Switzerland) & $\$ 958$ \\
Groupe Limagrain (France) & $\$ 622$ \\
Grupo Pulsar (Seminis) Mexico & $\$ 474$ \\
Advanta (AstraZeneca \& Cosun) (UK \& Netherlands) & $\$ 373$ \\
Dow (\& Cargill North America) USA & $\$ 350$ \\
KWS AG (Germany) & $\$ 332$ \\
Delta \& Pine Land (USA) & $\$ 301$ \\
Aventis (France) & $\$ 267$
\end{tabular}

(Source: Action Group on Erosion, Technology, and Concentration (formerly RAFI) 2001, p. 9) 
Figure 2. Industrial Concentration in Agricultural Biotechnology

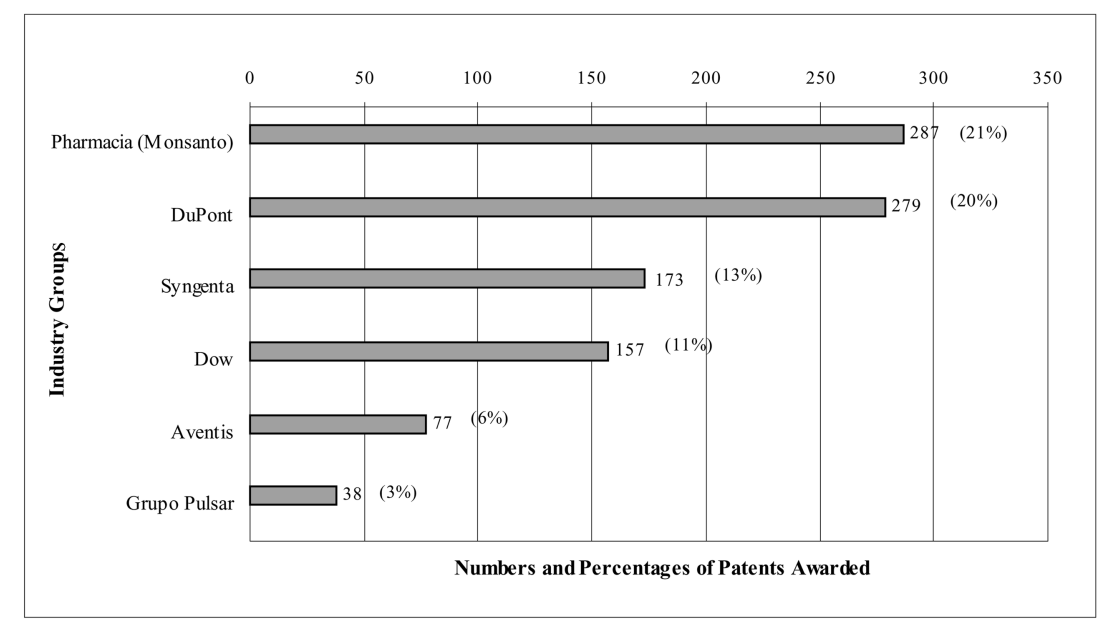

(Source: Action Group on Erosion, Technology, and Concentration (formerly RAFI) 2000, p. 9)

varieties and introducing the "terminator technology" which renders seeds nonreproductive in their next cycle. Farmers are bound to purchase seed each year which is not a viable option in poverty stricken areas (ACF, 2001; Green Planet International e-Gazette, 2002).

\section{Consumer Perceptions of Food and Agriculture Biotechnology}

In today's market, GM foods include such products as cotton, beef, milk, chicken, soybeans, corn/maize, canola, cotton seed oil, sugar beet, bacterial starter (cultures and enzymes), fungi (enzymes for bread, beer and fruit juices), and potatoes (Clinch-Jones, 2003).

However, consumers are demonstrating an increasing distrust of the use of genome technology in their food production and an increasing awareness of the need for consumer choice created through clear labelling of GM foods. The case in point has been clearly demonstrated by the European Union member nations continuing effective moratorium on the importation of GM foods. Consumer perceptions of GM foods, GM agriculture and other biotechnology applications are ambivalent at best.

Extensive research has been conducted on respondents in the 15 European Union member nations with regard to their attitudes to the use of technologies generally and biotechnologies specifically. Of the six major applications of 
biotechnology (including genetic testing, cloning human cells, using GM enzymes for soaps, xenotransplantation, GM crops and GM foods), Europeans are somewhat optimistic with regard to the applications related to medical and enzyme technology and particularly unsupportive when it comes to applications for agriculture and food (Eurobarometer 58.0, 2002). This is important as it demonstrates that consumers are aware and discerning of the development and application of varieties of technologies and biotechnologies in particular. They are not simply 'technophobic'.

On a country by country basis, when asked whether or not consumers support biotechnology applications to food and crops, up to 76 percent of the populations of various countries indicated they completely reject the implementation of GM foods. Up to 46 percent also reject the implementation of GM crops as demonstrated in Figure 3.

When presented with hypothetical situations which asked consumers to indicate their attitudes to purchasing and eating GM foods, the majority of consumers across Europe expressed the opinion that they would not buy or eat GM foods. "In some countries more than 50 percent of respondents rejected all of the six reasons offered [for buying or eating GM foods]" (Eurobarometer 58.0 2002, p. 37).

It also needs to be stressed here that these figures are taken only from those participants who had decided (either in support or opposition) on their response so

Figure 3. Level of Opposition to GM Foods and GM Crops in European Union Member Nations for the Year 2002.

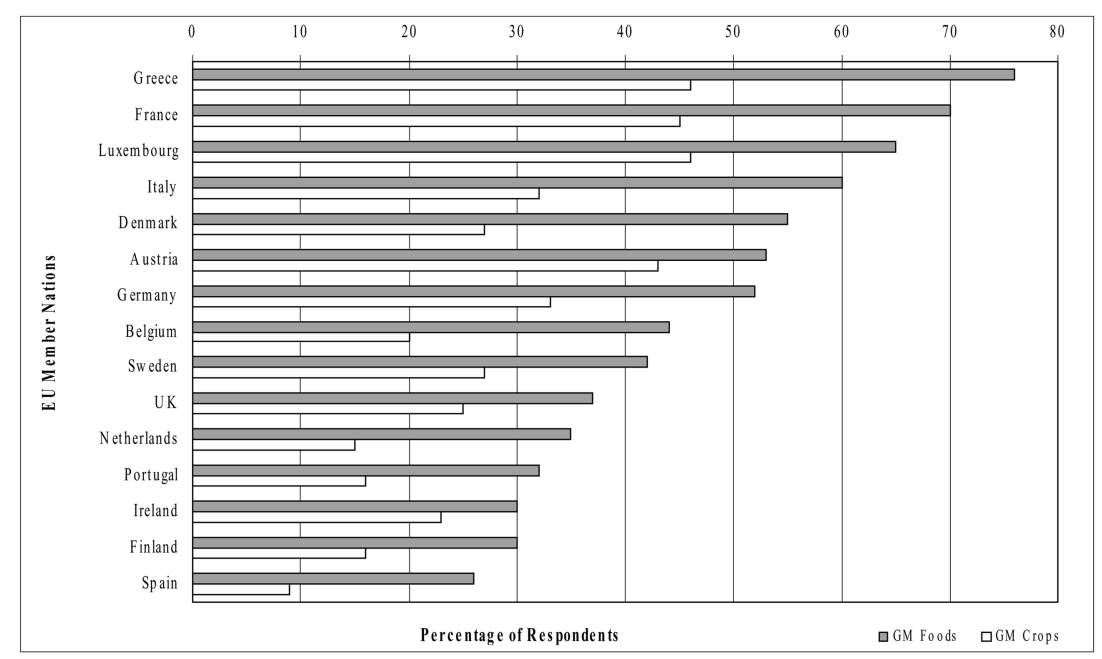

(Source: Adapted from Eurobarometer 58.0 2002, p.37) 
Table 3. Absolute Percentage of Populations for EU Member Nations in Support of GM Crops and GM Foods

\begin{tabular}{lcccccc}
\hline \multicolumn{5}{c}{\begin{tabular}{c} 
Supporters for GM foods and Crops (Absolute percentage of population) \\
\multicolumn{1}{c}{ Natons }
\end{tabular}} & $\begin{array}{c}\text { GM Crops } \\
\text { GM Foods }\end{array}$ \\
Greece & 1996 & 1999 & 2002 & 1996 & 1999 & 2002 \\
France & 45 & 22 & 24 & 28 & 9 & 11 \\
Luxembourg & 46 & 26 & 25 & 31 & 17 & 14 \\
Italy & 41 & 21 & 24 & 32 & 15 & 16 \\
Denmark & 50 & 38 & 31 & 35 & 24 & 18 \\
Austria & 39 & 28 & 33 & 25 & 17 & 20 \\
Germany & 23 & 20 & 26 & 18 & 15 & 21 \\
Belgium & 42 & 34 & 30 & 32 & 24 & 22 \\
Sweden & 52 & 36 & 36 & 42 & 23 & 25 \\
UK & 42 & 30 & 33 & 24 & 20 & 26 \\
Netherlands & 49 & 31 & 34 & 39 & 23 & 28 \\
Porthgal & 50 & 40 & 38 & 45 & 37 & 29 \\
Ireland & 52 & 40 & 38 & 42 & 27 & 31 \\
Finland & 49 & 33 & 35 & 42 & 27 & 32 \\
Spain & 51 & 40 & 38 & 45 & 34 & 32 \\
Averages & 50 & 43 & 41 & 46 & 34 & 33 \\
\hline
\end{tabular}

(Source: Adapted from Eurobarometer 58.0 2002, p. 37)

that in the year 2002, these percentages of country respondents are based on only 45 percent of the total sample of 16,500 participants. This means that some 55 percent of the sample is unaccounted for in these data. To account for this loss of data, we can calculate the percentages of support per country over the total populations.

This table clearly demonstrates that when extrapolated over the total population, the support for GM foods is at most one third of the population (Spain) while in Greece the support is only 11 percent. The figures highlighted at the bottom of the table display the average support for GM foods and crops for each of the three years. In 2002, less than one quarter of the population of the EU member nations supported GM foods and just under one third of the total population supported GM crops.

The Economist (2003, p. 114) also looks at the GM food debate with a brief discussion on the state of consumer perceptions in $14 \mathrm{EU}$ accession countries ${ }^{1}$. Of

${ }^{1}$ Eu accession countires include: Latvia, Slovenia, Cyprus, Estonia, Hungry, Romania*, Turkey*, Poland, Lithuania, Slovakia, Czech Republic, Bulgaria* and Malta (wher *are not in current accession). 
the more than 12,000 respondents surveyed, more than 80 percent felt that "science would improve their lives", however " $68 \%$ rejected GM food, with more than half believing the stuff to be positively dangerous".

While thus far the information has concentrated on the consumer perceptions of the European Community, other research indicates an eroding of trust for GM foods in North American nations where the majority of GM foods originate. As the Directorate-General for Agriculture (2003, p. 2) states:

In 1997, Novartis found that only $25 \%$ of Americans would be likely to avoid labelled GE foods. However, two years later, the poll commissioned by Time magazine indicated that 58\% of American consumers would avoid purchasing [labelled GE foods] (Centre for Food Safety, 1999).

The growing negative sentiment across the world prompted Europes largest bank the Deutsche Bank to advise thousands of its institutional investors to sell their shares of biotech companies. In its report, the bank has stated that "the message is a scary one - increasingly GMOs are, in our opinion, becoming a liability to farmers" (see Brown and Vidal, 1999). Many large insurance companies such as Swiss Re are refusing to insure any risks associated with GMOs (Lehmann, 1999).

\section{Agriculture Biotechnology and Developing Nations}

We examine the relevance of application of GM agriculture to developing countries and small and medium holding farms which comprise the majority of the developing nations agricultural scene.

Based on the data from a study involving more than four million farms in 52 countries covering 3 percent of the agricultural crop land in the developing nations, a recent editorial of New Scientist has noted that sustainable agriculture is pushing up crop yields on poor farms across the world often by 70 percent or more and stated that a "new science-based revolution is gaining strength built on real research into what works best on the small farms where a billion or more of the world's hungry live and work" (New Scientist, 2001, p.3; Pretty, 1997). Government policy and public interest research should play a vital role in developing ecological agriculture which focuses on wider community issues and priorities including areas such as energy, natural resource management, food quality and nutrition, 
health, biodiversity, and social and environmental consequences of agricultural technologies (Walter, 2002). These wider issues should be taken into account in trade disputes and negotiations relating to agricultural products.

Some of the major arguments put forward by proponents of biotechnology include:

(i) the benefits that will accrue from increased productivity, nutrition and health benefits, such as the use of so-called "Golden Rice" which is publicized as part of the solution to malnutrition in underdeveloped countries;

(ii) reduced use of pesticides; and

(iii) environmental sustainability and food security for developing nations (Hossain et al. 2002; Clinch-Jones, 2003).

We will examine these issues separately in the context of developing nations. Studies are showing that the increased productivity of GM crops is perhaps not all it should be. Examples include the 1997 failure of 30,000 acres of herbicideresistant cotton in the Mississippi region of the US with some farmers facing losses of $\$ 500,000$ to $\$ 1$ million. Georgia in the former USSR experienced losses of up to two thirds of a crop of insect-resistant 'New Leaf' potatoes; and the herbicide glyphosate-resistant soybeans (so-called "Round Up Ready") shows losses of between 4 percent and 10 percent when compared to conventional soybeans (Clinch-Jones, 2003).

These figures when compared with some of the techniques employed in many developing nations, which actually raise production yields and cost significantly less environmentally, socially and financially, give rise to pause before implementing further GM experimentation. Examples include:

- yields in many of the east African nations have been raised by 60-70 percent without the use of pesticide or GM technology simply by practicing the organic technique of companion planting (Pearce, 2001).

- Cuba is in the process of developing small-scale agricultural production due to the break-up of the former USSR and the now severe lack of access to fuel and agricultural inputs which support large-scale farming techniques. The Cuban Government is encouraging organic agricultural techniques and even "urban gardening" to provide food for their population (Magdoff, Foster and Buttel, 2000).

- In Ethiopia some 12,500 households have assumed sustainable agricultural practices which are raising yields up to 60 percent (Ho and Ching, 2003).

- Madagascar demonstrates that a system of rice intensification can improve 
yields from 2 tonnes per hectare to between 5 and 15 tonnes per hectare (Ho and Ching, 2003); and

- Sri Lanka has reduced insecticide use through sustainable practices on some 33,000 hectares of cultivation with the result of increased yields of 12-44 percent for rice and some 7-44 percent for vegetables (Ho and Ching, 2003).

The "Golden Rice" issue is also worthy of brief mention. Golden Rice has taken some 10 years and over $\$ 100$ million in development. It is a genetically engineered (GE) breed of rice which has been developed by introducing three genes two from a daffodil and one from a bacterium into a japonica rice strain that produces a yellowish rice with higher levels of beta-carotene which is converted into vitamin A. Proponents of Golden Rice have proclaimed it as a miracle cure and could save a million kids a year from blindness as Vitamin A is demonstrably lacking in a number of developing countries and is a major cause of blindness in children. However a careful examination of the science and economics show that this GE rice is not only unwanted but could have a variety of dangerous consequences to environment and human health. The undesirable and hazardous consequences of Golden Rice include, inter alia, (i) it is made with a combination of genes and genetic material from bacteria and viruses which are associated with diseases in plants and from other non-food items; (ii) the gene constructs are new and have never existed in nature; (iii) over-expression of transgenes linked to viral promotors such as that from cauliflower mosaic virus (CaMV) increases unintended metabolic affects. One of the CaMV promoters in Golden Rice is linked to antibiotic resistance marker gene; (iv) horizontal gene transfers from Golden Rice could spread transgenes including antibiotic resistance genes to bacterial pathogens, and also a potential to create new viruses and bacteria associated with diseases. Golden Rice also raises other concerns that are usually associated with all GM crops (Institute of Science in Society, 2003). Even for the proponents of Golden Rice there is not a great deal of dietary improvement in terms of vitamin A. As Brown (2001) suggests, if "consumers were on a diet of $300 \mathrm{~g}$ of the GM rice a day the average consumption of an Asian adult it would provide only 8 percent of the required daily intake of Vitamin A ... an adult would, in effect, have to eat 9 kilograms of cooked rice ... to satisfy the required intake and a pregnant woman would need twice that amount". Moreover poorly fed people (for whom Golden Rice is intended) are unlikely to absorb beta-carotene from Golden Rice. These people need a balanced and diverse diet including green leafy vegetables. There are innumerable small scale, ecologically friendly, low-tech and cost-effective alternatives involving 
production and consumption of diverse diets rich in Vitamin A. Besides, Vitamin $\mathrm{A}$ is inexpensive and easily manufacturable without the environmental risk associated with Golden Rice. Instead of encouraging biodiversity, Golden Rice could promote monocultures and genetic uniformity (similar to the Green Revolution of the 70s and 80s). Thus the introduction of Golden Rice is unsuitable as a strategy to address nutritional issues (see also Shiva, 2000).

The opposite of GM technology and monopolistic control of international seed markets has been established as a viable and sustainable alternative to agricultural production in small and medium sized farms and family farms in developing countries. The notion of international food security demands that nations gain respect for their rights to achieve a level of self-sufficiency in agricultural production "without suffering retaliation" (Sexton, 1999). Indeed as Sexton (1999) indicates, the WTO's agricultural agreements which require nations to open agricultural markets without the capacity for self-determination as to the legitimacy of that trade needs renegotiation. GM production and trade further raises both poverty and inequality of incomes and assets (Shiva, 1999).

In contrast to the practice of developing farm technology through the traditional cross-breeding techniques and the development of locally appropriate strains of crops and livestock, large investments in agricultural biotechnology are perhaps in severe opposition to the food security that these traditional methods provide. It is argued that GMOs actually contributes to food insecurity through the following issues:

- the technology may be unsafe for human consumption;

- the technology does not address the underlying factors of food access and poverty; and

- that the technological advancement actually provides a legal means for exploitation of poor populations (Globalization Research Centre, 2003).

Developing countries should promote farming methods which use labor intensive and ecologically friendly technologies that increase productive employment for the poor, and generate incomes in the rural sectors. This will ensure that the increased supply does not result in 'poverty and famine in the midst of plenty' but matched by demand created by increased rural incomes (Dreze and Sen, 1990). The current industrial farming with heavy dependence on toxic chemicals and non-renewable resources is not sustainable worldwide. Thus developing nations should focus on increasing agricultural supply through scientific and technological research in the direction of ecological farming and not in genetic 
modifications and monoculture technologies which significantly increase global monopoly control, environmental risks and global and regional inequalities. It should be noted that even though the income elasticity of demand for food falls, the income elasticity of demand for ecologically and ethically produced food products would still be rising (Halweil, 2001; Willer and Yussefi, 2001). This will also ensure a fair terms-of-trade from the premium price in the international market for the eco-friendly food and crops from developing countries.

\section{The Biosafety Protocol}

In January 2000, the Cartagena Protocol on Biosafety was signed by a number of concerned countries around the world - excluding those of the Miami Group including USA, Canada, Argentina, Uruguay, Australia and Chile, who ostensibly control the world's production of GM foods. The Miami Group protested the protocol through the use of WTO rules. The Biosafety Protocol sets out to ensure a level of protection for safety in handling and transfer of "living modified organisms resulting from modern biotechnology that may have adverse effects on the conservation and sustainable use of biological diversity" (Secretariat of the Convention on Biological Diversity, 2000, p. 3).

The Biosafety Protocol clearly sets out rules for trade in genetically modified organisms and allows governments to restrict the import of GM seeds and crops where the 'precautionary principle' would suggest that insufficient knowledge is held about the associated risks of these imports. In effect, it allows governments to regulate in the case of multi-national corporations and place the burden of proof against risk firmly back within the corporation's responsibilities (World Development Movement, 2000). We recommend the adoption of the principles of the Biosafety Protocol on the grounds of the 'precautionary principle'. Corporations and countries must demonstrate an awareness of the possible adverse implications of the development of biotechnology on humans and the environment.

\section{Concluding remarks}

World agriculture is at the crossroads. On one side, we have governments, corporations and farmers in the USA, who are aggressively promoting GM methods. Lack of stringent regulations on agriculture production methods in countries like the USA puts pressure on other countries to follow a minimal regulation approach, 
resulting in a 'race-to-the-bottom' in the regulatory framework in order to stay competitive in the global economy. This leads to a situation wherein 'bad crops drive away good crops', resulting in global cultivation of a few high yielding monoculture and GM crops sacrificing bio-diversity and increasing risk. On the other side, many European countries are actively promoting ecological farming methods through appropriate government policies and putting severe restrictions on GM technologies and products (Pillarisetti, 2002).

While biotechnology could have many useful applications in medical and other arenas, GM foods and crops are undesirable from a number of points of view. Firstly, the rationale behind the use of GMOs is unsound with no significant research detailing long term effects of GMOs on humans and the environment. Second, GMOs ignore ecological, social and ethical concerns of the world communities. Third, the GM food and seed production is highly concentrated geographically and industrially with a few countries and a few mega corporations embarking on this pursuit. Fourth, consumers across the world are rejecting GM foods and crops and are willing to pay high premiums for GM-free food. Finally, GMOs are completely unsuitable for developing nations from a variety of perspectives (Shiva, 1999).

Current WTO rules promote a minimal regulation approach in agriculture. USA and Canada with 82 percent of world GM crops are putting pressure on other countries to accept GM foods when no long-term safety studies are available. The result is that the 'market failure' is globalised and the role of government policy is undermined by WTO rules. Governments should have control in protecting their agriculture and citizens. A broad spectrum of scientists, environmentalists, religious leaders, and non-government organisations (NGOs) have voiced their concerns about the possible disastrous effects of untested GM technologies on human health and the environment.

Ironically, the aggressive public relation campaigns by GM companies have produced a negative effect with more and more people rejecting these foods. A number of issues are making GMOs an 'economic nightmare' including: class action law suits against GM companies from many NGOs, farmers and citizens across the world; a growth in resentment and the resulting falling prices and collapsing export markets; and the losses in production and profits. But a lack of adequate rules from WTO would enable GM crops to pose a serious and possibly irreversible danger to organic and bio-dynamic agriculture worldwide. Our paper argues that the 'precautionary principle' should be applied such that governments 
can take a long-term approach to agriculture, trade and the environment (Herstgaard, 2000). Food issues should be regarded in a comprehensive and holistic manner which includes the contextual environments of ethical production, economic sustainability, religion and culture, ecology, health and community well being.

\section{Acknowledgements}

The authors wish to thank Ashwath Nanjappa and John Rolfe and other anonymous referees for their helpful comments. The authors are responsible for all errors

Received 7 August 2003, Accepted 31 March 2004

\section{References}

Anderson, K. (2000) Agricultures multifunctionality and the WTO, The Australian Journal of Agricultural and Resource Economics, v.44, no.3, pp.475-494.

Atlantic Salmon Federation (2001) Catastrophic salmon escape prompts calls for moratorium, Environmental New Network, February 22.

Australian Conservation Foundation (2001) Genetic Jeopardy (Genetically Engineered Organisms, Module 17. [online] <www.acfonline.org.au>

Biodemocracy News (2001) Frankenfoods, antibiotics, and mad cow: Americas food safety crisis intensifies, Biodemocracy News, v.31, January, pp.1-5.

Brown, P. (2001) GM Rice Promoters have gone too far, The Guardian, UK [online] <www.biotech-info.net/too_far.html>.

Brown, P. and Vidal, J. (1999) Get out of genetic food stocks: Deutsche Bank, The Age August 26 [online] <www.gene.ch>.

Browne, A.W., Harris, P.J.C., Hofny-Collins, A.H., Pasiecznic, N., and. Wallace, R. R (2000) Organic production and ethical trade: definition, practice and links, Food Policy, vol.25, pp.69-89.

Chapman, C (1999) Agriculture and the WTO, International Faculty Council, University of Washington, Washington. [online] <www.washington.edu/wto/issues/ agriculture.html>

Clinch-Jones, K. (2003) Genetically Engineered Food, [online] <www.acnem.org/articles/ genetically_engineered_food.htm>.

Crouch, M. (1995) Biotechnology is not compatible with sustainable agriculture, Journal of Agricultural and Environmental Ethics, vol.8, pp. 98-111.

Directorate-General for Agriculture (2003) Economic Impacts of Genetically Modified 
Crops on the Agri-Food Sector (Working Document), The European Commission. [online] <europa.eu.int/comm/agriculture/publi/gmo/ch4.htm>.

Dreze, J and Sen, A. (eds) (1990) The Political Economy of Hunger, Vol II: Famine, Clarendon Press: Oxford.

Economist, The (2003) Genetically modified food, The Economist, April 5.

Environmental Research Foundation (1999) Genetically Altering the Worlds Food, Environmental Research Foundation, Rachels Environment \& Health Weekly \#639 [online] < www.cqs.com/news/rehw/r639.htm>.

Esty, D.C. and Geradin, D. (1998) Environmental protection and international competitiveness: a conceptual framework, Journal of World Trade, vol.32, pp. 5-46.

Eurobarometer 58.0 (2002) Europeans and Biotechnology in 2002 (2 ${ }^{\text {nd }}$ Edn.), Directorate General Press and Communication, Public Opinion Analysis Unit, London.

Globalization Research Centre (2003) Globalization and Food Security. [online] <www.globalhawaii.org/PDF/Food_security.pdf>.

Green Planet International (2002) Genetically Modified Food Friend or Foe?, Green Planet e-Gazette, Vol. 2, Issue 19, October 31 2002. [online] <www.greenmatters.net/ egazette/geneticfood2.19.htm>.

Halweil, B. (2000) Transgenic crop area surges, in Starke, L (ed.) Vital Signs 2000, W.W. Norton: New York and London.

Halweil, B. (2001) Organic gold rush, World Watch, May/June <www.worldwatch.org>.

Hayden, T. (2003) GMO Issue Intensifies Globalization/WTO Debate, Organic Consumers Association June 23, 2003. [online] <www.washington.edu/wto/issues/ agriculture.html>.

Herstgaard, M. (2000) A global green deal, Time, April/May, pp.82-83.

Ho, M. and Ching, L. (eds) (2003) The Case for a GM-free Sustainable World Independent Science Panel, Institute of Science in Society, London.

Hossain, F., Onyango, B., Adelaja, A., Schilling, B. and Hallman, W. (2002) Consumer Acceptance of Food Biotechnology: Willingness to buy genetically modified food products, Food Policy Institute, New Brunswick.

Institute of Science in Society, (2003) The Golden Rice An Exercise in how not to do Science, <www.i-sis.org.uk/rice.php>.

Jackson, D.A. and Stich, S.P. (eds) (1979) The Recombinant DNA Debate, Prentice-Hall, Inc., Englewood Cliffs, NJ.

Kanniah, R (2001) Genetically Engineered Food Production: Civil Society Responses, Paper presented at the National Convention on Consumer Protection, Calcutta, India, 10 February 2001.

Kimbrell, A. (ed) (2002) Fatal Harvest: the Tragedy of Industrial Agriculture, Island Press: Washington DC.

Lehmann, V. (1999) GM seed industry under pressure, Biotechnology and Development Monitor, v.39, pp.16.

Magdoff, F., Foster, J.B. and Buttel, F.H. (2000) Hungry for Profit the agribusiness threat to farmers, food, and the environment, Monthly Review Press, September 2000. 
[online] <http://www.monthlyreview.org/hfpintro.htm>.

Mellon, M., Benbrook, C., Benbrook, K.L. (2001) Hogging It: Estimates of Antimicrobial Abuse in Livestock, Union of Concerned Scientists: Cambridge, MA.

Muir, W.M. and Howard, R.D. (1996) Possible ecological risks of transgenic organism release when transgenes affect mating success: sexual selection and the Trozan gene hypothesis, Proceedings of the National Academy of Sciences, Vol.96 (24), pp. 13853-13856.

New Scientist (2001) The greener revolution, New Scientist, Vol. 169 (2276), p.3.

Pearce, F. (2001) An Ordinary Miracle, New Scientist, Vol 169 (2276), p. 16.

Physicians and Scientists for Responsible Application of Science and Technology (1998), Inadequate safety assessment of GE food, Nov 3, 1998, [online] <www.psrast.org/ subeqow.htm>.

Pillarisetti, J. R. (2002) World trade in environmentally sustainable agriculture: policy issues for Australia, Journal of Economic and Social Policy, Vol.7(2), pp. 66-82.

Pretty, J.N. (1997) Sustainable agriculture, people and the resource base: impact on food production, Forum for Development Studies, Vol.0, n.1, pp.7-32.

Pretty, J.N, Brett, C., Gee, D., Hine, R.E., Mason, C.F., Morison, J.I.L., Raven, H., Rayment, M.D., and Van der Bijl, G. (2000) An assessment of total external costs of U.K. agriculture, Agricultural Systems, Vol.65, no.2, pp.113-136.

Rissler, J. and Mellon, M. (1996) The Ecological Risks of Engineered Crops, The MIT Press: Cambridge, Mass.

Rural Advancement Foundation International (2001) Globalization, Inc. Concentration in Corporate power, The Unmentioned Agenda, Action Group on Erosion, Technology, and Concentration (formerly RAFI) Communique Issue \# 71, July/August 2001, Winnipeg.

Rural Migration News (2001) Mad cows, GMOs, Rural Migration News, Vol.7, n.2, pp.13.

Secretariat of the Convention on Biological Diversity (2000) Cartagena Protocol on Biosafety to the Convention on Biological Diversity, Secretariat of the Convention on Biological Diversity, Montreal.

Sexton, S. (1999) The world is hungry for justice, not genetics, Health Matters, Issue 36, Spring. [online] <www.healthmatters.org.uk/stories/sexton36.html >.

Shiva, V. (1997) Biopiracy: the Plunder of Nature and Knowledge, South End Press, Cambridge, MA.

Shiva, V. (1999) Stolen Harvest: the Hijacking of the Global Food Supply, South End Press, Cambridge, MA.

Shiva, V. (2000) GE Vitamin A Boosted Rice A Blind Approach to Preventing Blindness, Australian GeneEthics Network. [online] <www.gene.ch/info4action /2000/Mar/ msg00002.html .

Simms, A (1999) Selling suicide farming, false promises and genetic engineering in developing countries, Christian Aid Week, May 1999. [online] <www.christianaid.org.uk/indepth/0001biot/biotech.htm>. 
United Nations Development Programme (1999) The Human Development Report 1999, UNDP: New York.

Vorman, J (2001) US Science Panel rejects StarLink in Human food, Reuters News Service, Planet Ark Update [online] <www.planetark.org/dailynewsstory. cfm?newsid=11812>.

Wallch, L. and Sforza, M. (1999) Whose Trade Organization?: Corporate Globalization and the Erosion of Democracy, Public Citizen Inc., Washington, D.C.

Walter, G.R. (2002) Economics, ecology-based communities, and sustainability, Ecological Economics, Vol.42 (1), pp.81-87.

Willer, H. and Yussefi, M. (2001) Organic Agriculture Worldwide 2001: Statistics and Future Prospects, Bad Durkheim: Stiftung Okologie \& Landbau (SOL, Foundation Ecology and Agriculture), Biofach and IFOAM.

World Development Movement (2000) GM Charter agreed in Montreal - Biosafety Protocol greeted with qualified optimism, Press Release 29 January 2000. [online] <www.wdm. org.uk/presrel/current/montreal3.htm>.

Wills, P R (2001) Witness Brief Royal Commission of Inquiry into Genetic Modification, GE free New Zealand. [online] 〈http://www.gmcommission. govt.nz/〉. 